型からマイナス $\mathbf{x}$ 秒すなわち，0.9 型 〜0 型のでとき減退状態となる。例示 すれば，口述面ではいわゆる同時通訳， 書寫面では同時翻訳人通するる方途を， 具現化する営みとも言えよう。

終りに，若干の要言を加えるならば， わたしたち日本人が日本語を話す場合， マが無く㧕揚にそしい，いわゆる「立 て板に水」式のしやべりかたには感心 できない点，外国語を話す場合にあり てあ同様である。けたし，話し手の言 語感情は，形一音声と影一Paus e と の相互反射一起伏一を通して, 聞き手 の聴覚心理に伝達され,さらに受け答 えされるあのであり．とのPauseの
果たす投影的機能は，まさしく，言語 表現上の功罪・評価を左右するに値す る，とみなすに足りょう。

如上の Pause を対象とし，今回は むつばら，L L 利用による実験理論一 分析的総合的原理一をまとめた次第で あるが，具象例に基つく音声生理的

(視覚器具併用) - 言語心理学(音波 測定機併用）成果の報告は，他日の機 会にゆだねたい。

[付記]本稿は，和年38 年5月 24 日秋田大学で開催された「第 12 回果 北中国学会大会の席上, 研究発表した 内容に若千補筆して成つたのであるる。

\title{
藤堂明保氏の<漢字の 語源研究》を読んで
}

鈴 木 直 治

1 との著者は, その「上古漢語の単 語家族の研究」という副題によつても 知られるように，上古に扔ける単語家 族についての著者多年の研究の成果を 発表したものであり，その「まえがき」 によれば，著者の学位論文を増補し， その解説を平易に改めたものである。

著者の単語家族についての研究は， その《中国語語源漫筆》(1955 年, 大学書林) の中に打いても，すで にその一端が示されて打り，いかゆる 「右文説」をはじめ，清朝の考証学者 の説を引用しながら，語氣の「家系譜」 を立てる学問の必要を力説し, Karl一 gren氏か', その《Word Fami- lies in Chinese》k扣いて, 同似の音節をむつた語の分類を試みて いるととを高く評価していたのである が，ての書においては，その上古漢語 の音韻論研究の成果を活用して《中 国音韻論》)(1957 年，江南書院 の著述がある），Karlgren氏欠欠 点を根本的に是正し，200項約 3100 字に及ぶ語笨を整理して，各類につい て，総括的にその類としての「基本義」 を解明するとと屯に，各字についても， 著者一流ひ明快な説明を加えているの であつて，ての習の干行によつて，を の研究成果を利用できるようになった ことは，わたくしの心加暂びとして 
いるとてろである。

2 著者は，その《漢文概説》

(1960年,秀英出版) ・ 《模文要説》

(1963 年, 秀英出版) 飞扔いて，

「漢字のヴェールをはがせ」という一 節を設けているのであるが，てれは， 著者の主張を示す重大な一つのスロ一 ガンとむいうべきあのである。著者は， これまでの文学学者が，ややむすれば， むつばらその字形の上からその原義を とらえようとする傾きのあるのに対し て，てとばの本質である語音を重視す べきととを主張し，上古の声母・親母 について，その通転を認めうる大枠を 示して, 再三にわたつて, 文学学者の 注意を喚起しているてとからしても 《東京支那学報》第3号1957年， 第6 号 1960 年)，著者の研究方法の 基調を知るととができる。

もとより，著者は，字形の研究を軽 視しているのではない。ての書の「ま えがき」の中にも，「甲骨・金文の研 究にあできるだけ目を注ぐ」というて とを，その研究方法の中の重要な一つ としてあげており，また，現にての書 の「序説」の中に，特に「字形に関す る諸問題」という一章を設け, 指示・ 会意の原則的な約束を表わす例を， 18 項 125 字について論述して, 「字形を見る心がまえ」を説いている のであって，てのことからしても，著 者の字形に対する研究のなみなみなら

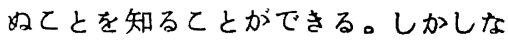
から，扔よを文字は，言語を目に訴元
る記号にすぎぬ以上, 漢字の字形が暗 示するのは，語義そのあのではなく， それは。たんに漢語を研究するための 一つの手がかりにすぎないというとと が (P.17)，乙の書を貫く著者の根本 的な主張である。

3 著者は, 本誌の第109号 (1961 年4月）、，「形態基という考元方」 という論文を発表しているのであるが。 ての論文は，単語家族研究についての 著者の基礎的な理論を明らかにしたも のである。「形態基」というのは，と の書の説明によれば，「その配下に多 くの形態素を擁する親概念であり，古 代人の頭脳の中に蓄えられていた単語 家族の抽象的な一々の型であつた」

(P.63) と考えられるあのである。 漢字の 1 字は, 打执む, その 1 形態 素に該当するわけである $(P .66) 。$ すなわち，一つの「形態基」は，その 音䫓構成の上に扣いて，その配下の各 字を統括する「基本型」をもち，それ らの漞概念としての「基本義」をもつ ものである。

この「形態基」を抽出するにあたつ て，著者は，恐らくは，ます第一に， 「右文説」の主張を承けて, 同一の音 符をむつ諧声語群に着目したととであ ろうか，著者は，ての場合に扔いても， 単にその用いられている音符の形の同 一なるととによつて，類を設けようと しているのではなく，その表記されて いる形をてえて，その推定される音 䫓構成の型と，それらのむのを貫く 
意味とによつて，その類をとらえょう としている。

それで，まず第一に，いかにして， その音韻構成の「基本型」を定めるへ きかということが問題になるのである が, 著者は，ての点については，上古 に扔ける声母・䫓母の体系と，その許 されうる通転の枠に，その基礎を扣い ているのであつて，てのてとか，まず 第一に，との書に扔ける単語家族の研 究方法の重要な特改の一つとして数え るべきであり，著者の研究方法の語学 的な緻密さを示すあのというととがで きる。

4 Karlgren氏に打引る単語家族 の研究は，漢字音の声母と韻尾だけに 着目して, 次のような12 種類の大枠 を設けたものにすぎなかつた。

$$
\begin{array}{llll}
\mathrm{K} \sim \mathrm{NG} & \mathrm{T} \sim \mathrm{NG} & \mathrm{N} \sim \mathrm{NG} & \mathrm{P} \sim \mathrm{NG} \\
\mathrm{K} \sim \mathrm{N} & \mathrm{T} \sim \mathrm{N} & \mathrm{N} \sim \mathrm{N} & \mathrm{P} \sim \mathrm{N} \\
\mathrm{K} \sim \mathrm{M} & \mathrm{T} \sim \mathrm{M} & \mathrm{N} \sim \mathrm{M} & \mathrm{P} \sim \mathrm{N}
\end{array}
$$

すなわち，Karlgren氏は，単語家 族の音䫓構成を考えるに当つて，母音 を除外した大枠を設けているのである が，このKarlgren氏のゃりかたは， 著者あ紹介しているように (P.25)， チベット語に扔いては，きわめて多く の母音の転化が行われて扰り，従つて， 同じ語根をあつ語の間に，さまざまな 䫓母が含まれているというととからし て，中国語についても，同様な現象が 見られるであろうという考えかたから なされているものである（張世氺氏訳 《漢語詞類》(1937 年・商務印
書館) P.107)。

Karlgren氏は, 以上 12 の大枠 の中に，約 2.400 の漢字をあげている のであるが，それは，もちろん，その 枠の中の語をととでとく同一家族のも のと断定し，更にそれらを貫く「基本 義」までをむ推定しているのではなく， それらのものは，そつ万能性があるの であるから，同一家族のものとしてお いてもさしつかえあるまいという意見 なのであり，てのょうな角度からして 材料を集めておくことは，シナ・チへ ツト語族の比較研究の基楚をなすもの であるという予想に立つているもので ある(張世称氏訳《漢語詞類》P. 108)。

Karlgren氏に打引る単語家族は， 以上のょうに，その単語家族としての 基本的な意味が具体的に考えられてい ないあのであり，それらは，はたして， 単語家族といいうるあのかどうか，き わめて不確実なものである。その音韻 構成の上に扔いて，母韻の性質を顧み ない以上，そのょうな不確実な漠然と したものとなることは，当然の結果で あろうと考えられる。しかしながら， 上古漢語に扔いては，「右文説」の人 々が指摘しているような諧声語群の上 からだけいってむ，同一の母音をむつ 確実な単語家族の存在していたととを 否定するてとはできない。それで， Karlgren氏のいうシナ・チベット 語族の比較研究をするためにも，まず この確実な単語家族の研究をより科学 
的により精密に行うべきあのであると 考える。著者か，々の単語家族の音䫓 構成上の「基本型」を定めるのに，前 述のょうに，その上古音䫓論の研究に よる声母と韻母との枠に立脚したとと は，乙のKarlgren氏の説の久点を 根本的に是正するあのとして，きわめ て大きな意義を有するあのと考える。 かつ, Karlgren氏は, その主要 母音についてだけではなく，介母のi とuとについても，同様にその単語家 族の枠に関係がないものとしているす であるが，著者は，その諧声語群につ いての研究加らして，介母のiは，そ の基本的な音韻構成に関係はないけれ ども, 介母のuの有無は, 重要な問題 であつて，無視するととのできないむ のであることを明らかにし，ての点か らしても，その単語家族の分類をより 精細なあのとしていることは，てれま た，その研究の緻密さを示すむのとし て，高く評価さるべきものである。 5 次に，単語家族に打ける「基本義」 のとらえかたの問題であるが，恐らく は，乙の点が，著者のもつとあ苦心さ れたところであろうかと考えられる。

一つの「形態基」は，前述のょうに， その音韻構成上の「基本型」とともに， その「形態基」としての「基本義」を もたなければならないものである。諧 声系列のものをむ含めて，ある若干数 の漢字について, 音韻構成上, 同一の 型のあのであるととを推定するてとが できたとしてす，それらのむのを貫く

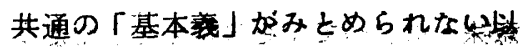
上，それらは，ある一つの「形態基」 に属する学語家族であるとはいいえな い。著者が自ら述へているように，

「各種の諧声系列が，一括して全部同 一の単語家族に属するならば，単語家 族の整理は，かなりらくになるであろ うが，しかし実際には，一々の諧声系 列の中に，たいてい幾つかの仮借字が 含まれている」(P.58)と洘えて扔 なければならないのであって，上古漢 語の中にも，同音異義語は，やはり， かなり多かつたあのにちがいない。そ れで，そのようなあのは，その「基 本型」が同じであっても，やはり， まず，異なつた単語家族のむのとして 扔かなければならない。

しかしながら，一見その同音異義語 のように思われるものの中にも，基本 的には，同系的なむの，または派生的 なものとして，同じ家族の中に収めう るものああるはずであり，それらのむ のは，当然同一の単語家族のものとし て取りあつかうべきであり，それらの むのを通じて，その「基本義」をとら えてゆくことが，是非必要なはずであ り，てのょうな努力なしには，単語家 族の研觉とはいいえない。ただ，その 判定の上にきわめて多くの困難があり, またその程度がきわめて大きな問題で ある。

著者は，その一つの単語家族に属す るむのとしてあげている個々の漢字に つい, その字形の暗示しているすの 
を活用し，古典に㕲る用例や先人の 注解尞引用するなとして，その篻語家 族のものと判定しうる理由を，きわめ て明快に説明しているのであつて，そ の独創的な解説のしかたは，著者の他 の論著にも多く見られるところであり， すでに定評のあるとてろであろうと考 える。しかし，ての㻎全体の上から見 て, 著者かての問題を解決するために 取つた基本的な方法は，一つの単語家 族の範囲を，まずできるだけ縮小して 取りあつかうということであつたよう

\section{亿考えられる。}

「基本義」というあのは，その単語 家族と推定されるものの中から，帰納 的に抽出されるべさあのである。それ で，その単語家族の範囲を搪大すれ代 するほど，その漞概念として「基本義」 は，ますます抽象的なむのにならざる をえないかけであり，そのように抽象 华すればするはど，主観的要素の入り こせ恐れの多いものと考えられる。著 者か，との算語家族の範囲を，最初か らまずあまり拡大しようとはせずに， むしろ, 比較的少数の漠字について， その「基本義」を抽出する方法を取つ ていることは，こうした主観的なもの に陷ることを避けようとしたてとによ る屯のと思われる。著者の「基本義」 に対するこのようなとらえかたは，前 述の「基本型」の定めかたとあいなら んで，ての畫机ける単語家族の研究 方法の重要な特改と見るべきすのであ り, 著者の研究方法の着䒠さを示して
いる6のということかできるてのよ 引以，その、基本義」の過度の抽象化 や主観化を避け，むしろその単語家族 の範囲を縮小したととによつて，Kar一 I g r e n 氏の単語家族に打けるいか加 あ粗雑な12 種類の大枠とは対照的に， 200 項に及ぶ単語家族をあげるに至 つているのであって, 基碗的な研究と しては，当然まずかくあるべすあのと 考える。

例えば，著者は，一つの単語家族と して,「光・黄・煌」など6字をあげ, その「基本型」を $\{$ KUANG\}とし， 「基本義」を「四方にひろかるひかり」 とし (PP.410〜413)，また，「王 皇殿」など21字を，また一つの単 語家族とし，その「基本型」を\{ $\mathrm{HU}$ $A N G\} と し ， 「$ 基本義」を「大きくひ 乃かる」としている(PP.413〜418)。 著者仗，声母の通転の枠からして，牙 音と殹音とは，\{K\}打よび $\{\mathrm{NG}\}$ として示しうる屯のとしているのであ り (P. $31 ， 63)$ ，また事実，「廣」は， kua と推定されているものなのであ るから，後者の「基本型」屯\{ $\mathrm{KUA}$ NG：としてもよいわけなのであり， それを\{HUANG\}というように示し たのは，「王・皇」なとの声母からと 推定されるととろから，との「王・皇」 などをむつてその単語家族を代表させ ようとしたものと考えられる。それで， この二つの単語家族としてあつかわれ ているものは，その「基本型」を同じ 型のものとすると、とができるばかりで 
はなく，その「基本義」の上において あ，あい通ずるとてろがあるように考 えられるが，著者自身も，「王中皇は， 打々く光や黄と同系であろう」( $\mathrm{P}$. 412 ) と述べているのであるが，なお もこれらを二つの単語家族としてあげ ているのは, 前述のように, 基礎的な 研究として，まずその単語家族の範囲 をあまり拡大しまいとする考えかたに よるあのと考えられる。

6 との書を通読すれば，それぞれに， 著者があげている単語家族の中には， 二者を統合して一つの類とするととが 適当であると考えられるすの，また， それとは反対に，更にその類を細分す るととが適当であると考えられるあの， また更に，個々の漢字について，その 所属の類を変えるととが適当であると 考えられるあのなどがあるとと考え られる。わたくしとしてあ，著者の説 に，そのままことでとくは賛成し難い 点む少なくないし, 今後学界の研究の 進展につれて，その説は，部分的にか なり改められるようになつてゆくあの と考える。しかじがら，ての上うな 研究の進展に伴う変更は，著者自らも 期待しているとてろなのであつて (P. 60)，わたくしは，まず，著者が単語 家族についての新しい研究方法の創始 者として，よくこの大著をなされたて とに対して，大きな敬意をはらわざる をえない。

著者が多年この単語家族の研究を進 めて来たのは, 一つには, 将来の比較
言語学のための基碟を固めようとする ことととあに，また一つには，古典の 解読をより正確なあのにするのに役立 てたいということを，その主なる目的 としていたあのであり（侀態基とい j考元方《《中国語学 109 号》), 著 者は自らく古代語の意味と古典の解読〉 《日本中国学会報・第13 集>9961 年) という論文を発表して，その単語 家族研究の成果に立脚して，「古典解 読の再検討」を主張している。

上古漢語の研究, 古典の解読にあた つては，いろいろな困難が多いのであ るが，そのもつとも大きな困難の一つ として，その字羲の精確な把握が難し いというととがあげられる。清儒は， 古典の解読にあたつて，字義の原初的 なるあのを，多くはまず説文てて求 めようとしていたのであるが，語策は 体系をなしているものである以上，坬 立的なむのとしてではなく，やはりま ず，ある類をなしているものとしてと らえててそ，よくその字義を明らかに するととができるあのであると考える。 著者は，との書に拈いて，各字の解説 にあたつて，その冒頭に，その推定さ れる上古音・中古音の次に，ますく説 文〉の本文をあげているのであるが， その各字の解説に入るに先だつて， まず類としてのその単語家族全体につ いての総説を行っているのであるから， ての書は，古典研究者のための新しい 説文〉となりうるあのであると考え る。 
最後に，あつとる遺减なことは，上 古漢語の侵部・种部と談部・葉部とい う部分が，この書の中には略されてい るということである。それは，「まえ がき」によれば,この書は, 文部省学 術図畵刊行助成金を受けて刊行したも のなのであるが，補助金支給の内示を 受けた後にも，なかなか刊行の引き受 け手がな，それに，補助刊行物飞課 せられた時間の制約のために，こんど の刊行に間に合わなかつたことによ
るすのとのことである。わたくしは， 日本に拉りる学術図書の刊行について のこのような現状に対して，一種のい きど拈りを感ずる。ただ，著者は，こ の書が売れ尽した後に，ふたたび同じ 出版社から，上記の部分䄪 30 項 500 字を続編として刊行したい考えでいる とのことである。でたすら，その続編 の刊行を待つ次第である。(学燈社発 行, 1963 年3 月)

$(1963.7 .12)$

\section{＜資料>}

\section{現代中国語概論}

(中国語研究入門)

$$
\begin{gathered}
\text { ヴェ・ェム・ソーンッェフ著 } \\
\text { (望月 八十吉 訳) }
\end{gathered}
$$

接辞的語構成法

主として古代のテキストによつて中 国語を研究した多くの中国学学者は， 中国語には，接辞的語構成法は存在し ないと考えた。

多くの学者，例えばB．カールグレ ンは,〈一子〉〈一頭〉〈一兒〉の上 ろな若干の接尾辞が存在することを指 摘しながらむ，中国語に接辞的語構成 法の存在することを原則的飞否定して いる。なぜなら，B・カールグレンは
「一羽の燕では春は来ない」と書いて いるから。

しかし、比較的小さい役割しか演し ないけれども，中国語には接辞的語構 成法が存在する。〔その役割は現在の ところ小さい】けれどあ，接辞によつ て構成される語の数は，たえず増大し ている。

語構成接辞は，主として名詞と存在 する。 